\title{
THE FOOD REQUIREMENTS OF CHILDREN
}

\section{CARBCHYDRATE REQUIREMENT}

\author{
L. EMMETT HOLT, M.D., AND HELEN L. FALES \\ NEW YORK
}

The carbohydrate in the diet of the growing child has, as far as is known, no specific function to perform. Nevertheless, it is a very essential component of the diet. It serves mainly as a source of energy, supplying the necessary calories which are not furnished by fat and protein. In so doing, however, carbohydrate accomplishes other purposes. It is the most efficient sparer of protein, being for this purpose superior to fat. This function of carbohydrate is so well known and has been so frequently discussed in the literature that it need not be taken up in detail here. It has been accepted generally that carbohydrate is essential for complete metabolism of fat, and that in the absence of carbohydrate from the diet, or when the amount is very low, fat is incompletely burned and acidosis may result.

When digestion is normal, a reasonable intake of carbohydrate is almost, if not quite, completely utilized in the body, leaving no residue to be eliminated in stools and urine. The excess that is not immediately used for energy is stored in the form of glycogen to be used later for energy or is converted into fat and added as such to the tissues of the body.

Carbohydrate is the most economical food from a physiologic as well as a commercial point of view. Physiologically, it is economical because of its complete utilization and because the energy required for digestion, that is, the "cost of digestion," is much lower than that of fat or protein. The commercial economy in carbohydrate foods is well known. They can be produced more cheaply than other foods; they can be stored for a long period without significant deterioration; they can be shipped and marketed in a compact form and are not readily affected by changes of temperature or by exposure. Because of these facts the market price of carbohydrate foods is much lower than that of the foods which are composed mainly of fat and protein. Table 1 gives the number of calories of carbohydrate which could be purchased for 10 cents at a small retail store in New York City, Feb. 1, 1922. For comparison are given the number of calories in fat and protein foods which could be purchased for the same amount at the same time and place.

* Received for publication, March 17, 1922.

* From the laboratories of the Rockefeller Institute for Medical Research and the Babies' Hospital. 
Carbohydrates form the greatest part of the diet of the human race at every period of life. The nursing infant receives a high proportion of carbohydrate as lactose in woman's milk, nearly one-half of the caloric value of the milk being due to the sugar. The nursing infant takes about $50 \mathrm{gm}$. lactose daily at the end of the first month and an average of $80 \mathrm{gm}$. daily during the latter part of the nursing period. Infants taking modifications of cow's milk usually receive more carbohydrate than do nursing infants. This is giver because the amount of fat in modifications of cow's milk is in most cases considerably lower than that in woman's milk. Although a higher proportion of protein is given, this does not entirely make up for the reduction in the calories furnished as fat and consequently a larger amount of carbohydrate must be supplied.

Table 1.-Calories Purchasable for Ten Cents. Feb. 1, 1922

\begin{tabular}{|c|c|c|}
\hline Articles & Retail Price & $\begin{array}{c}\text { Number of } \\
\text { Calories }\end{array}$ \\
\hline \multicolumn{3}{|l|}{ Carbohydrate Foods: } \\
\hline Sugar. granulated............. & 6 cents per pound..................... & 3,100 \\
\hline Karo corn syrup............... & 20 cents per 2.5 pound ean................ & 1,970 \\
\hline 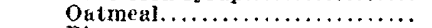 & 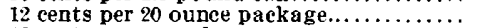 & 1,980 \\
\hline Rice. $\ldots \ldots \ldots \ldots \ldots \ldots \ldots \ldots \ldots$ & 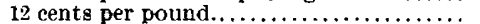 & 1,360 \\
\hline$\ldots \ldots \ldots \ldots \ldots$ & 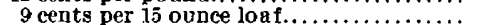 & 1,270 \\
\hline Cream of wheat.............. & 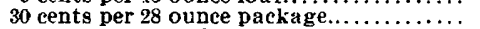 & 980 \\
\hline 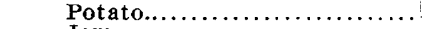 & 5 cents per pound...................... & 770 \\
\hline 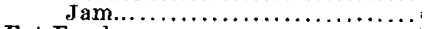 & 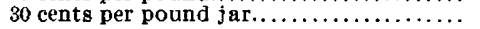 & $\mathbf{5 3 0}$ \\
\hline \multicolumn{3}{|c|}{. } \\
\hline Butter... & 49 cents per pound..... & 740 \\
\hline $\begin{array}{l}\text { Olive oil... Sheffield } \mathrm{x} \text { (includes } \\
\text { Cream, }\end{array}$ & 65 cents per pint........ & 600 \\
\hline \multirow{4}{*}{ 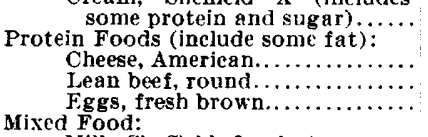 } & 32 cents per half pint... & 240 \\
\hline & 35 cents per pound. & 590 \\
\hline & 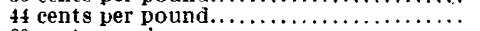 & 200 \\
\hline & 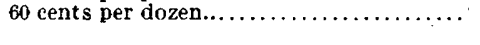 & 180 \\
\hline Milk, Sheffield, Grade A......... & 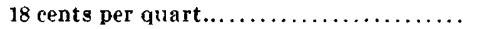 & $3 \overline{5} \overline{5}$ \\
\hline
\end{tabular}

The nursing infant receives carbohydrate entirely in the form of lactose. The infant on modifications of cow's milk may take lactose entirely or part lactose and part saccharose, maltose, dextrin, or starch, or a combination of these. It is not usual for any large proportion of the carbohydrate to be given as starch during the first year. When a mixed diet is taken at least one-half of the carbohydrate is usually in the form of starch, the rest being sugars-lactose, saccharose and fructose with occasionally a certain amount of dextrin and maitose.

The amount of carbohydrate taken by children more than 1 year of age varies according to the theories of the physician and the notions of the parent and even more according to the habits and tastes of the child. The carbohydrate variation is greater than that of any other constituent of the diet. Some children habitually take large amounts of bread, others live mainly on cereals, while with still others potatoes form the predominant article of diet. Many children consume an excessive amount of sugar, taking several teaspoonfuls on cereal and in 
other foods and sometimes even having sugar added to the milk taken. The relative amount of sugar taken by these children is steadily increased with age, since the child's palate demands a marked degree of sweetness in all foods and will not take those which do not taste sweet. In such cases the amount of sugar consumed soon forms a surprisingly large proportion of the diet to the exclusion of the other needed constituents.

Many children take, besides the amount of granulated sugar eaten with foods, a great deal in the form of jam, marmalade, jelly or syrup. It is often forgotten that syrup and honey are practically pure carbohydrate in a concentrated form, and that jam, marmalade and jelly usually contain from 80 to 90 per cent. sugar. Many a mother or physician who would think an ounce of granulated sugar excessive does not realize that an ounce of syrup or a rounded tablespoonful of jam contains practically the same amount of sugar. To these sources of carbohydrate must be added candy. There are few children who get no candy and the majority take several pieces and not a few as much as half a pound daily. A small piece of candy is equivalent to about one teaspoonful of sugar. It is obvious that a few pieces of candy increase the carbohydrate intake appreciably.

The degree to which sugar has come to form a prominent part of the diet of the American people is a cause for serious reflection. One hundred years ago the consumption of granulated sugar averaged only 8 pounds per capita. Last year the average was 84 pounds. The amount consumed as candy is a very large item in sugar consumption. The statement was made a few years ago by an official of a corporation operating 5 and 10 cent stores that their annual sales of candy exceeded 60,000 tons.

The carbohydrate intake of more than a hundred healthy children specially studied by us is shown in Charts 1 and 2 . In Chart 1 are given the values in grams of the total carbohydrate taken daily. The curves shown are those representing the grams of carbohydrate which would be required to supply 50 per cent. of the total calories which are needed, according to our estimates, ${ }^{1}$ at the different ages. Our investigations have shown that this proportion of the total calories, that is, 50 per cent., is the average taken as carbohydrate by a normal healthy child. The figures on which this average is based will be presented later.

In Chart 2 are given the values for the carbohydrate intake in grams per kilogram of body weight. The curves represent the grams of carbohydrate supplying 50 per cent. of the caloric requirement per kilo.

Charts 1 and 2 illustrate the wide variation in the carbohydrate intake of healthy children. This is most evident in the chart showing grams per kilogram. There are more very high values than very low

1. Holt, L. E., and Fales, H. L.: Am. J. Dis. Child. 21:1 (Jan.) 1921. 
ones and several instances of an intake of more than $15 \mathrm{gm}$. carbohydrate per kilogram. Chart 1 shows that there was more consistency in the total amount of carbohydrate taken daily. There are few low values, but several exceedingly high ones. One girl, 8 years of age,
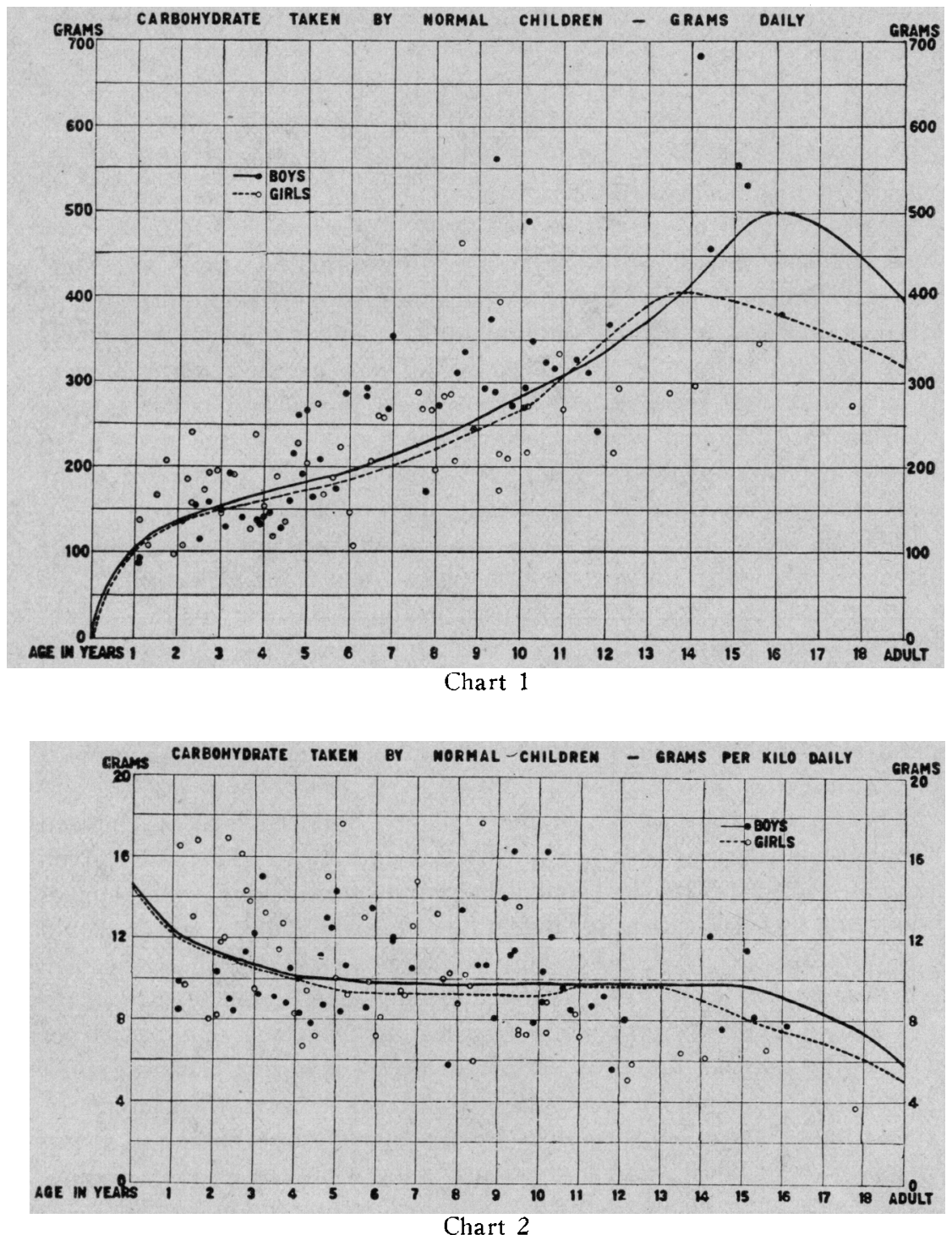

took $464 \mathrm{gm}$. carbohydrate daily. One boy, 9 years of age, took 560 gm.; another, aged 10, took $488 \mathrm{gm}$. and one, aged 14, took $683 \mathrm{gm}$. daily.

The average intake according to years is shown in Table 2, which gives the values for boys and girls separately and for both sexes grcuped 
together. It will be seen that the total daily intake increases with fair regularity with the years, while the intake per kilogram decreases with. the years. The average of all the cases, regardless of age, is about $10 \mathrm{gm}$. per kilogram. It is interesting to note that the carbohydrate intake per kilogram of the boys aged 14 to 16 showed a marked increase over that of the boys a little younger.

The observations reported in the literature, in which the carbohydrate intake of children after infancy was ascertained, show variations quite as wide as those in our own cases. As a rule, the amount of carbohydrate per kilogram of body weight taken by young children was higher than that taken by older children. The children studied by Müller ${ }^{2}$ had very high intakes of carbohydrate, nearly all over $10 \mathrm{gm}$. per kilogram, while several children took as much as $17 \mathrm{gm}$. The intake of carbohydrate in Camerer's cases was low, as were the other

TABLE 2.-Average Carbohydrate Intake of Children.

Original Observations

\begin{tabular}{|c|c|c|c|c|c|c|c|c|c|}
\hline \multirow{3}{*}{$\begin{array}{l}\text { Age. } \\
\text { Years }\end{array}$} & \multicolumn{3}{|c|}{ Boys } & \multicolumn{3}{|c|}{ Gilis } & \multicolumn{3}{|c|}{ Both Sexes } \\
\hline & \multirow{2}{*}{$\begin{array}{c}\text { No. of } \\
\text { Cases }\end{array}$} & \multicolumn{2}{|c|}{ C-H Intake } & \multirow{2}{*}{$\begin{array}{l}\text { No. of } \\
\text { Cases }\end{array}$} & \multicolumn{2}{|c|}{$\mathrm{C}-\mathrm{H}$ Intake } & \multirow{2}{*}{$\begin{array}{l}\text { No. of } \\
\text { Cases }\end{array}$} & \multicolumn{2}{|c|}{ C-H Intake } \\
\hline & & $\begin{array}{l}\text { Total } \\
\text { Gm. } \\
\text { Daily }\end{array}$ & $\begin{array}{l}\text { Gm. } \\
\text { per } \\
\text { Kg. }\end{array}$ & & $\begin{array}{c}\text { Total } \\
\text { Gm. } \\
\text { Daily }\end{array}$ & $\begin{array}{l}\text { Gm. } \\
\text { per } \\
\text { Kg. }\end{array}$ & & $\begin{array}{c}\text { Totul } \\
\text { Gm. } \\
\text { Daily }\end{array}$ & $\begin{array}{l}\text { Gm. } \\
\text { per } \\
\text { Kg. }\end{array}$ \\
\hline $\begin{array}{c}1-2 \\
2-3 \\
3-4 \\
4-5 \\
5-6 \\
6-7 \\
7-8 \\
8-9 \\
9-10 \\
10-11 \\
11-12 \\
12-13 \\
13-14 \\
14-15 \\
15-16 \\
16-17 \\
17-15\end{array}$ & $\begin{array}{l}2 \\
4 \\
6 \\
7 \\
5 \\
3 \\
2 \\
4 \\
5 \\
6 \\
3 \\
1 \\
\dddot{2} \\
2 \\
1 \\
\cdots\end{array}$ & $\begin{array}{r}90 \\
142 \\
147 \\
178 \\
219 \\
280 \\
261 \\
291 \\
357 \\
338 \\
292 \\
366 \\
571 \\
541 \\
380 \\
\cdots\end{array}$ & $\begin{array}{r}9.2 \\
10.0 \\
10.9 \\
10.2 \\
11.1 \\
11.5 \\
10.3 \\
10.8 \\
12.2 \\
10.9 \\
7.8 \\
8.0 \\
\ldots .0 \\
9.9 \\
9.6 \\
7.8 \\
\ldots \ldots\end{array}$ & $\begin{array}{l}5 \\
7 \\
4 \\
5 \\
5 \\
5 \\
3 \\
5 \\
4 \\
3 \\
1 \\
2 \\
1 \\
1 \\
1 \\
3 \\
1\end{array}$ & $\begin{array}{l}154 \\
179 \\
176 \\
166 \\
211 \\
196 \\
274 \\
288 \\
247 \\
279 \\
268 \\
257 \\
287 \\
296 \\
346 \\
20 \\
272\end{array}$ & $\begin{array}{r}12.8 \\
13.3 \\
11.7 \\
9.4 \\
11.9 \\
9.3 \\
11.2 \\
10.5 \\
8.9 \\
8.5 \\
7.2 \\
5.5 \\
6.4 \\
6.2 \\
6.6 \\
\ldots . . \\
4.8\end{array}$ & $\begin{array}{r}7 \\
11 \\
10 \\
12 \\
10 \\
8 \\
5 \\
9 \\
9 \\
9 \\
4 \\
3 \\
1 \\
3 \\
3 \\
1 \\
1\end{array}$ & $\begin{array}{l}128 \\
165 \\
158 \\
173 \\
215 \\
228 \\
269 \\
289 \\
308 \\
317 \\
286 \\
293 \\
287 \\
480 \\
476 \\
380 \\
272\end{array}$ & $\begin{array}{r}11.8 \\
12.1 \\
11.2 \\
9.8 \\
11.5 \\
10.1 \\
10.8 \\
10.6 \\
10.7 \\
10.2 \\
7.7 \\
6.3 \\
13.1 \\
8.1 . \\
8.1 \\
7.8 \\
4.5\end{array}$ \\
\hline
\end{tabular}

constituents. Gephart ${ }^{3}$ found that the amount of carbohydrate taken by the boys of St. Paul's School was much in excess of the average adult consumption, averaging more than $600 \mathrm{gm}$. daily. This represents an average of $13.7 \mathrm{gm}$. per kilogram for the youngest group of boys who averaged 13 years of age, $12.4 \mathrm{gm}$. per kilo for the group of boys who averaged $141 / 2$ years and $9.9 \mathrm{gm}$. for those averaging 16 years.

The amount of carbohydrate in the usual adult dietary is from 400 to $550 \mathrm{gm}$. daily, which represents from 5 to $8 \mathrm{gm}$. per kilogram of body weight.

2. Müller, E.: Biochem. Ztschr. 5:143. 1907.

3. Gephart, F. C.: Boston M. \& S. J. 176:17, 1917. 
Murlin ${ }^{4}$ found that the men in the United States Army training camps took on the average $545 \mathrm{gm}$. carbohydrate daily. This is equivalent to $8.2 \mathrm{gm}$. per kilogram, the average weight being 146 pounds, or 66.5 kilograms.

From the data obtained concerning the diet taken by the normal children studied by us it was possible to calculate approximately the amounts of carbohydrate taken as sugar and as starch by these children. The values obtained are only approximate, since the relative amounts of sugar and starch used in cooking the various articles, such as cake, pudding, etc., could, in most cases, be only estimated from a knowledge of common recipés. It may be assumed, however, that our estimates are reasonably accurate.

It is surprising that the average of all the cases, regardless of age, showed that 51 per cent. of the carbohydrate intake was in some form of sugar. The proportion of sugar ranged from 27 to 82 per cent., but more than two-thirds of the values were between 40 and 60 per

Table 3.-Average Amounts of Starch and Sugar Taken

\begin{tabular}{|c|c|c|c|c|c|c|c|c|}
\hline \multirow{2}{*}{$\begin{array}{l}\text { Age in } \\
\text { Years }\end{array}$} & \multirow{2}{*}{$\begin{array}{l}\text { No. of } \\
\text { Cases }\end{array}$} & \multicolumn{2}{|c|}{ Gm. Carbohydrate as } & \multirow{2}{*}{$\begin{array}{c}\text { Age in } \\
\text { Years }\end{array}$} & \multirow{2}{*}{$\begin{array}{l}\text { No. of } \\
\text { Cases }\end{array}$} & \multicolumn{3}{|c|}{ Gm. Carbohydrate as } \\
\hline & & Starch & Sugar & & & Starch & 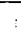 & Sugar \\
\hline $\begin{array}{l}1-2 \\
2-3 \\
3-4 \\
4-5 \\
5-6 \\
6-7 \\
7-8 \\
\varepsilon-9 \\
6-10\end{array}$ & $\begin{array}{r}7 \\
11 \\
10 \\
12 \\
10 \\
8 \\
5 \\
9 \\
9\end{array}$ & $\begin{array}{r}65 \\
71 \\
85 \\
86 \\
101 \\
111 \\
137 \\
128 \\
149\end{array}$ & $\begin{array}{r}63 \\
94 \\
73 \\
87 \\
114 \\
117 \\
132 \\
161 \\
159\end{array}$ & $\begin{array}{l}10-11 \\
11-12 \\
12-13 \\
13-14 \\
14-15 \\
15-16 \\
16-17 \\
17-18\end{array}$ & $\begin{array}{l}9 \\
4 \\
3 \\
1 \\
3 \\
3 \\
1 \\
1\end{array}$ & $\begin{array}{l}161 \\
136 \\
162 \\
133 \\
277 \\
229 \\
216 \\
108\end{array}$ & $i$ & $\begin{array}{l}15 \% \\
150 \\
131 \\
154 \\
203 \\
247 \\
164 \\
164\end{array}$ \\
\hline
\end{tabular}

cent. In Chart 3 are given the proportions of starch and sugar taken by each child, arranged according to age. This shows that there is comparatively little individual variation in the distribution of the carbohydrate intake as starch and sugar. It is apparently usual in the mixed diet of children to give practically equal amounts of starch and sugar. It should be noted that the value for sugar includes not only the saccharose used in cooking or on cereals, etc., but also the fruit sugars and the lactose of the milk which was taken separately or which was used in the preparation of other foods.

Table 3 gives the average values according to years for the daily intake of starch and sugar.

It was also possible to estimate roughly the proportion of different sugars which made up the sugar intake. Some interesting observations were thus brought out. Table 4 shows the averages, according to years, of the grams of lactose, saccharose and fruit sugars taken by the children studied. It will be seen that the lactose intake does not vary

4. Murlin, J. R., and Hildebrandt, F. M.: Am. J. Physiol. 49:531, 1919. 


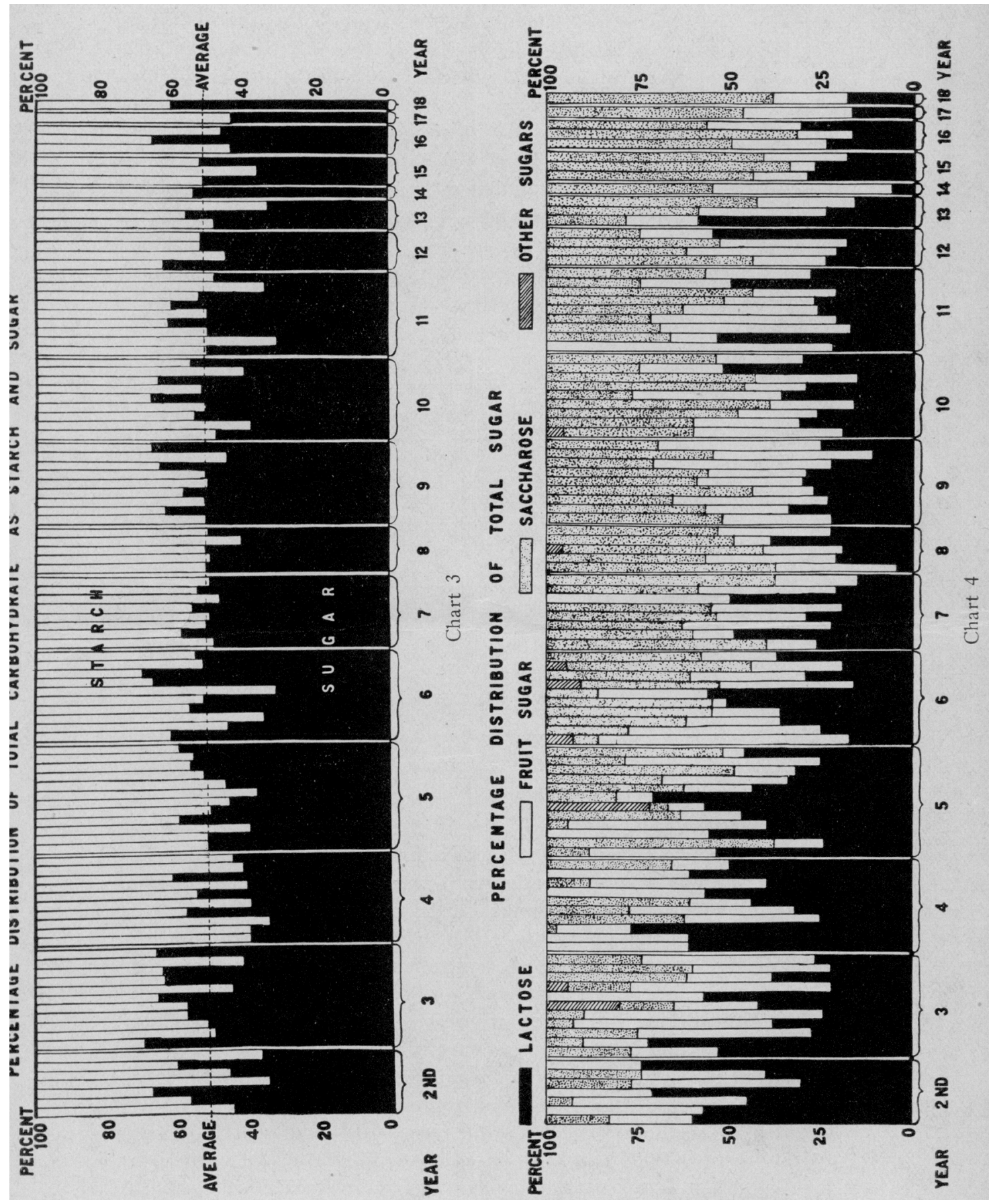

Downloaded From: http://archpedi.jamanetwork.com/ by a Oakland University User on 06/03/2015 
widely. The saccharose taken, however, shows an almost steady increase with age up to the eleventh year, with a marked increase during adolescence, the amount taken at that time being about ten times as much as the average taken by children under 4 years. It is surprising to note how much of the sugar was supplied by fruits. This value includes all the carbohydrate in the fruit. This is largely fructose but some of it is saccharose, and there is included in some instances a small amount of starch, for example, in apples and bananas when not thoroughly ripe.

In Chart 4 are shown the percentages of the total carbohydrate taken as different sugars by each child, the values being arranged according to age.

Table 4.--Average Amounts of Different Sugars Taken

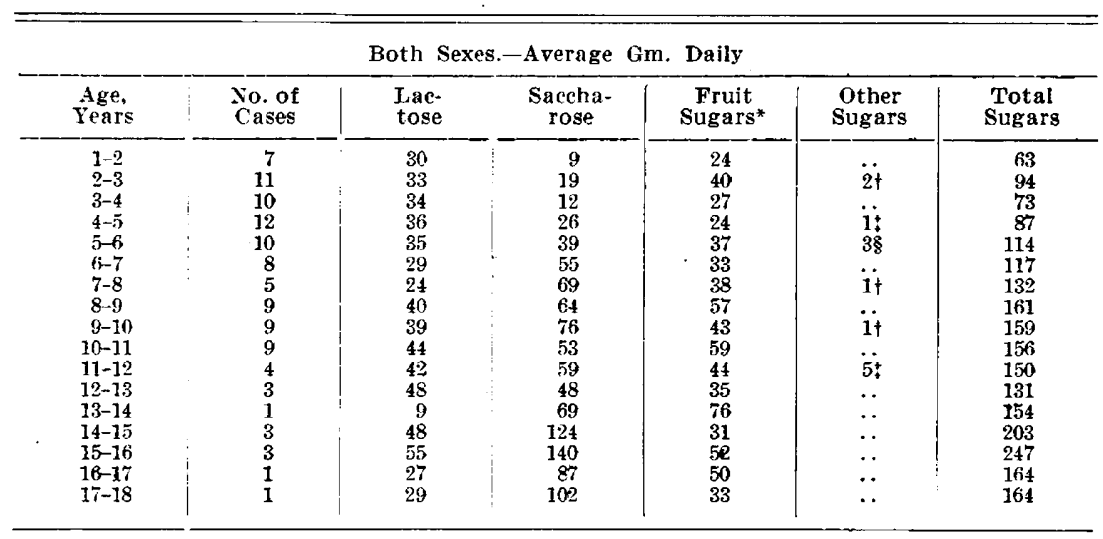

* This includes all sugars occurring in fruit taken; largely fructose, but includes considerable saccharose and occasionally very small amounts of starch.

Honey (levulose and dextrose).

Maltose.
Honey and maltose.

The economic advantage of carbohydrate foods over fats and proteins has brought about a tendency to allow carbohydrate to form an excessive proportion of the modern diet. There are several important disadvantages in this procedure. The production of diabetes must be reckoned as a possible danger, as has recently been suggested. ${ }^{5}$ If the proper caloric intake is maintained, a very high proportion of carbohydrate necessitates a low proportion of either fat or protein. Hence, there is a possible danger of reducing the amount of fat or protein below that which is necessary for normal nutrition. When a diet high in carbohydrate and low in fat and protein is taken, there may result an excessive retention of water in the tissues of the body. High carbohydrate feeding leads also to an excessive deposition of fat in the body. This condition is often seen in infants fed on sweetened condensed

5. Michea1, J. C.: Arch. Dermat. \& Syph. 2:455 (Oct.) 1920. 
milk or on the proprietary foods, which are chiefly carbohydrate. It is quite usual with such feeding to achieve a rapid gain in weight. Infants fed in this way, however, are usually found to have very low resistance to infection. Their tissues are high in fat and water.but low in muscle. When a digestive disturbance occurs, or when an infection takes place, this unnatural weight is rapidly lost and the child often succumbs readily. A similar condition was produced experimentally in pigs by Washburn and Jones. ${ }^{6}$ They found that young pigs fed on sweetened condensed milk put on an excessive amount of fat. The protein increase in their bodies was, however, much below normal, and the bone development was defective, the bones being only two-thirds as strong as when whole milk was fed. Table 5 gives a summary of some of their findings.

There is a growing belief that the large and constantly increasing proportion of carbohydrate in the diet of civilized races has a very important relation to the prevalence of dental caries. It has been

TABLE 5. - Comparison of Growth in Seven Weeks of Six Pigs on Condensed Milk with Six Pigs on Whole Milk

\begin{tabular}{|c|c|c|c|c|c|}
\hline Feeding & $\begin{array}{l}\text { Calorie } \\
\text { Intake } \\
\text { Daily }\end{array}$ & $\begin{array}{c}\text { Weight, } \\
\text { Gain in } \\
\text { Kg. }\end{array}$ & $\begin{array}{l}\text { Fat, } \\
\text { per Cent. } \\
\text { of Gain }\end{array}$ & $\begin{array}{c}\text { Protein, } \\
\text { per Cent. } \\
\text { of Gain }\end{array}$ & $\begin{array}{c}\text { Breaking } \\
\text { Strength } \\
\text { of Femur in } \\
\text { Pounds }\end{array}$ \\
\hline 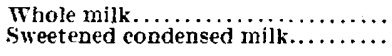 & $\begin{array}{l}1,370 \\
1,270\end{array}$ & $\begin{array}{r}11.35 \\
8.10\end{array}$ & $\begin{array}{c}9.2 \\
23.65\end{array}$ & $\begin{array}{l}15.61 \\
10.92\end{array}$ & $\begin{array}{l}36 ? \\
243\end{array}$ \\
\hline
\end{tabular}

observed that Arctic peoples, whose diet is almost entirely fat and protein with but very little carbohydrate-and that usually in the form of starch, rarely suffer from dental caries.

Stefansson, the Arctic explorer, has stated that he himself has examined 500 skulls which were dug up from an old cemetery in Iceland of about the eleventh century. In only one skull was an imperfect tooth found and that was evidently the result of injury. He further stated that the Eskimos who live on a meat diet have perfect teeth, but, when they come in contact with civilization and eat the foods of other races they suffer severely from dental caries.

Furthermore, archeologic researches have shown that dental caries was prevalent in ancient Egypt. More recently the discovery of a very primitive human skull in Rhodesia has shown that dental caries existed in earliest times. Both of these localities are tropical or subtropical in climate and the early diet was probably composed largely of plant foods and hence was predominantly a carbohydrate diet, a complete contrast to that taken by the Arctic peoples.

6. Washburn, R. M., and Jones, C. H.: Vermont Agric. Exper. Sta. Bull. 195. 
Whether the tendency to dental caries is due to an excess of carbohydrate or to a consequent reduction of other constituents of the dietfat, protein, mineral salts or vitamins-has not yet been established.

Of great importance, also, is the effect on digestion of a diet in which the proportion of carbohydrate is excessive. When a very large amount of carbohydrate, especially in the form of sugar, is taken into the digestive tract at one time, it is often impossible for absorption to take care of it. The consequence of this is excessive fermentation in the intestine, due to bacterial action, with the formation of carbon dioxid and organic acids, which may be very irritating to the mucous membrane of the intestine. This excess of acid usually causes a quickened peristalsis with large, loose, acid stools. The result is a decreased absorption of all the food constituents and frequently a serious diarrhea: When the diet contains an excess of carbohydrate in the form of starch, somewhat different symptoms frequently develop. There is often constipation, great abdominal distention, flatulence and colic.

TABlE 6.-Grams of Carbohydrate Combined with One Gram Vegetable Protein

\begin{tabular}{|c|c|c|c|}
\hline Food & $\begin{array}{l}\text { Gm. Carbo- } \\
\text { hydrate } \\
\text { per Gm. } \\
\text { Protein }\end{array}$ & Food & $\begin{array}{c}\text { Gm. Carbo- } \\
\text { hydrate } \\
\text { per Gm. } \\
\text { Protein }\end{array}$ \\
\hline 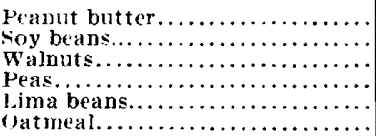 & $\begin{array}{l}0.6 \\
0.6 \\
0.7 \\
2.4 \\
3.7 \\
4.2\end{array}$ & 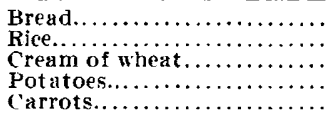 & $\begin{array}{l}5.8 \\
6.4 \\
6.9 \\
8.4 \\
8.4\end{array}$ \\
\hline
\end{tabular}

Usually these disorders of digestion are acute and not very severe, yielding quickly to proper dietetic treatment. When, however, they are frequently repeated or are prolonged through lack of proper dietary adjustment, they lead to serious chronic disturbances with marked loss in weight. This condition is often difficult to control and a very great reduction in the carbohydrate of the diet is required for a long time before the normal tolerance for carbohydrate is reestablished. This condition is most frequently seen in the second and third years of life.

In the discussion of the protein requirement of the child we have stated that if vegetable proteins are depended on to supply the protein need during growth very large amounts of carbohydrate are inevitably given, since vegetable proteins occur only in combination with large amounts of starch. Table 6 shows the amount of carbohydrate, usually in the form of starch, which is combined and necessarily given with each gram of vegetable protein in some common foods. It will be seen from this table that nuts and soy beans are the only foods which supply much vegetab!e protein without including very large amounts of carbohydrate. 
Although nuts have been found to be well utilized by adults without disturbance of digestion, the wisdom of giving them to children in any considerable quantity is questionable. It is not advisable to depend on them as a source of protein. It would appear from its chemical composition that the soy bean is an excellent source of vegetable protein. This vegetable, used so extensively in China, is not familiar to the American people. It has a peculiar flavor, not very palatable according to our tastes, and on that account will probably not gain any great popularity in this country, where other sources of protein are readily available.

In the other articles of food which supply vegetable protein there is so much carbohydrate combined with the protein that there is danger of serious disturbance of digestion from the excess of carbohydrate. It is evident that for this reason alone, as well as for the others given in a preceding article, it is not wise to depend on vegetable foods to stupply the protein need of the child.

As has already been stated, in addition to the positive harm which may follow excessive use of carbohydrate in the diet of the child, there must always be considered the additional disadvantage which follows this plan of feeding because of the inevitable reduction of fat and protein.

It has been shown that a definite amount of protein should be included in the diet of the growing child. ${ }^{7}$ It seems rational to allow in the diet at least as much fat as protein. ${ }^{8}$ The total calories needed at any age can be estimated with a fair degree of accuracy. ${ }^{1}$ Hence, the amount of carbohydrate required is determined by subtracting from the total caloric need the calories supplied by the needed amounts of fat and protein. On this basis there should be allowed for the healthy child of average activity about $12 \mathrm{gm}$. carbohydrate per kilogram at 1 year, decreasing to between 9 and $10 \mathrm{gm}$. or about 1 per cent. of the body weight, at 6 years and maintaining about this value throughout the remainder of the growth period.

If the total caloric need is raised above the average by increased muscular activity, carbohydrate may be used to provide the entire amount of extra energy, since an increase in muscular activity does not increase the needs in protein or fat above the normal.

\section{SUMMARY}

1. Carbohydrate is a desirable and probably an essential component of the diet, although it does not have any specific function in nutrition. It forms the largest part of the diet at all periods of life.

2. Nursing infants take on the average about $12 \mathrm{gm}$. carbohydrate per kilogram of body weight daily. Artificially fed infants usually receive somewhat more than this.

7. Holt, L. E., and Fales, H. L.: Am. J. Dis. Child. 22:371 (Oct.) 1921.

8. Holt, L. E., and Fales, H. L.: Am. J. Dis. Child., to be published. 
3. The carbohydrate in the diet of the infant is almost all sugar, that of the nursing infant entirely lactose, that of the artificially fed infant usually a mixture of lactose with saccharose or maltose and dextrins.

4. The carbohydrate intake of more than one hundred healthy children from 1 to 18 years of age, studied by us, averaged 10 gnı. per kilogram. Of this 51 per cent. was sugar, including lactose, saccharose and fructose, and 49 per cent. was starch.

5. Carbohydrate is more economical than fat or protein, both physiologically and commercially. Because of this latter advantage there is a growing tendency to increase the proportion of carbohydrate in the diet beyond the amount which is desirable.

6. When a very large proportion of the food is in the form of carbohydrate, the intake of fat or of protein or of both is likely to be less than the normal nutritive need of the body.

7. A diet excessive in carbohydrate leads to an abnormal deposition of fat without a corresponding increase in muscle development. Chilclren taking such a diet have feeble resistance to infection.

8. There is evidence that a relationship exists between the high proportion of carbohydrate in the modern diet and the prevalence of dental caries.

9. Definite digestive disturbances, chiefly intestinal, may be produced when the carbohydrate in the diet is excessive. There may result increased fermentation with loose acid stools or constipation with flatulence and abdominal distention. When long continued these disturbances are very difficult to control.

10. Carbohydrate furnishes the calories needed in the diet which are not supplied by the requisite amounts of fat and protein.

11. It seems rational to allow in the diet of the child of average activity about $12 \mathrm{gm}$. carbohydrate per kilogram of body weight at one year, decreasing the amount to about $10 \mathrm{gm}$. per kilogram at 6 years and maintaining it at this value throughout the remainder of the growth period.

12. An increase in the total caloric need because of increased activity may be supplied by carbohydrate alone. 